\title{
Cornides István (1920-1999) a hazai tömegspektrometria megteremtője
}

\author{
KÉKI Sándor ${ }^{\mathrm{a}^{*}}$, LELIK Lászlób \\ ${ }^{a}$ Debreceni Egyetem, Természettudományi és Technológiai Kar, Alkalmazott Kémiai Tanszék \\ Egyetem tér 1., 4032 Debrecen, Magyarország \\ ${ }^{b}$ Szent István Egyetem, Élelmiszertudományi Kar, Élelmiszerkémiai és Táplálkozástudományi Tanszék, Somlói u. 14-16., \\ 1118 Budapest, Magyarország
}

Nehéz egy írást elkezdeni arról az Emberről, aki sokoldalúságával és mindennapjaival sok-sok élményt nyújtott életében nemcsak nekünk, de szerte a magyarok lakta területeken élő embereknek.

Nekem (L. L.) ilyenkor mindig az az emlék tolul elő, amikor kandidátusi disszertációm bírálatakor Erika írógépén leírta, hogy ,,a dolgozat meglepően kevés gépelelési (kiemelés tőlem: L. L.) hibát tartalmaz" (a bírálat azóta is féltett kincs számomra).

$\mathrm{Ki}$ is volt Cornides István, mindenki Pista bácsija?

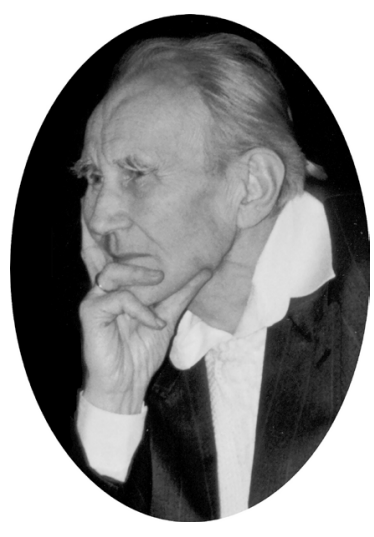

Dr. Cornides István

Dr. Cornides István apai részről az erdélyi Kornis nemesi család egyik kisnemesi ágának, míg anyai ágon a Borcsányi nemesi család leszármazottjaként 1920. december 7-én született a felvidéki Komjáton.

Az I. világháború utáni, viharokkal tűzdelt időszakban, ahogy azt Cornides István többször is nyilatkozta, még magyar állampolgárként született az akkori Magyarország Nyitra vármegyéjében. Magyar állampolgársága annak volt köszönhető, hogy a trianoni békeszerződés hatályba lépésére, a születését követő évben, 1921-ben került sor.

Életútját és pályafutását, az oktatás és a kutatás iránt érzett elkötelezettségét és hivatásszeretetét alapvetően meghatározta vallásos neveltetése, a szülők és a nagyszülők példamutatása, ember- és hazaszeretete. Révkomáromban a Bencés Gimnáziumban érettségizett.
Cornides István gimnáziumi évei alatt kiváltképp a történelem iránt érdeklődött, tudásvágyából fakadóan végigolvasta anyai nagyapja könyvtárában található „Magyarország városai és vármegyéi” címü teljes könyvsorozatot. A történelem mellett, középiskolai bencés tanárának, Gidro Bonifácnak köszönhetően egyre jobban és mélyebben érdeklődött a matematika és általában a természettudományok iránt. ${ }^{1}$ A Felvidék visszacsatolása után a Pázmány Péter (a későbbi Eötvös Loránd) Tudományegyetem matematika-fizika szakos hallgatója, majd 1942-től az Eötvös Kollégium tagja lesz.

Munkabírása, elméleti és gyakorlati problémák megoldása iránti fogékonysága már fiatal évei alatt megnyilvánultak. 1942-től a Gyakorlati Fizikai Intézetben a később Nobeldíjjal kitüntetett Békésy György (1. ábra) munkatársa, díjtalan tanársegéd, ahogyan írta ,afféle elötornász, akinek a tanár megmutatja az új fogásokat, hogy adja tovább és gyakoroltassa be a többiekkel”. Békésy György ekkor dolgozza ki az egyetem számára a kísérleti és gyakorlati fizika korszerű tanításának koncepcióját és kezdi meg annak bevezetését. Ehhez választja munkatársaként Cornides Istvánt (demonstrátorként). ${ }^{1,2}$

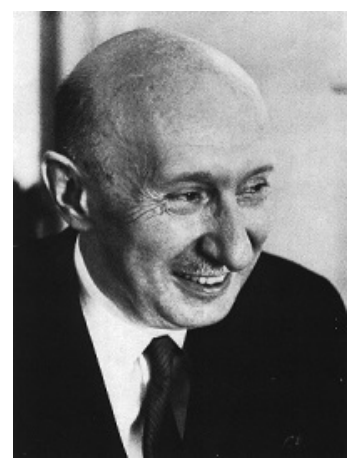

1. ábra. Békésy György (forrás: http://members.iif.hu/visontay/ ponticulus/rovatok/hidverok/bekesy-tarnoczy.html)

Tehetségének, kitartásának és mai szóhasználattal élve, innovatív gondolkodásmódjának köszönhetően kulcsszereplője lett a Békésy-féle fizika tantárgyreformnak, amelynek elindításában és végrehajtásában oroszlánrésze volt, új, modern, gyakorlatorientált fizikai laboratóriumi gyakorlatok megvalósításával és bevezetésével. Az általa, e területen végzett munka elismerését mi sem bizonyítja jobban,

* Prof. Dr. Kéki Sándor: keki.sandor@science.unideb.hu 
mint a nem éppen dicséret osztogatásairól ismert Békésy Györgynek, Cornides Istvánhoz intézett következő mondatai: „Tudja, most már azt kell mondanom, hogy ez a tanszék, a fizikaoktatás kezd hasonlítani arra, amit elképzeltem. És ebben magának is része van."1 Cornides István fö demonstrátori, illetve gyakornoki tevékenysége a II. világháború viharos időszakára esett, és még e nehéz időkben is Békésy György közbenjárására sikerült elkerülnie a katonai szolgálatot egészen 1944 októberéig. A nyilas hatalomátvételt követően, Békésy katonai szervekkel való kapcsolatának megszünésével Cornides István ,védettsége” is szertefoszlott, így még ez évben megkapta a behívóparancsot egy kárpátaljai honvéd hegyivadász zászlóaljhoz. Angol hadifogságot követően, 1946-ban térhetett haza. Azonnal munkához látott a budapesti Tudományegyetemen, azonban ekkor már egykori professzorával nem találkozhatott. Békésy, Cornides érkezése előtt egy nappal már elhagyta az országot. Békésy ajánlásával rögtön elkezdett labort vezetni korábbi tanszékén. Az 1948-ban kezdődött tisztogatások miatt jelentkezett fizikatanárnak a ciszterci rend Feneketlen-tó melletti Szent Imre Gimnáziumába is.

1946 és 1956 közötti időszakban politikai hullámokkal, intoleranciával és sokszor inkompetenciával átszőtt környezetben folytatta azt a munkát, amelyet korábban elkezdett, méltó folytatásaként Békésy szellemi örökségének. ${ }^{1-3}$

Az 1950-es évek elején kapcsolódik be az akkor még Magyarországon új területnek számító tömegspektrometriai kutatásokba, és ettől kezdve e terület meghatározó szerepet játszik Cornides István további szakmai pályafutásában. Korai tömegspektrometriás munkái közül kiemelendő a rádiófrekvenciás $(\mathrm{RF})$ tömeganalizátorok elméleti leírása az optikai rács analógiája alapján, ${ }^{4}$ valamint az RFanalizátorok felbontóképességének javítása és alkalmazása izotópok szétválasztására. ${ }^{5}$ Bár egyetemi pályafutása folyamatosan borotvaélen táncolt, mégis ebben az időszakban építette meg az első magyar tömegspektrométert, amelynek felbontása 120 volt. Ekkor - a felbontóképesség további javítása érdekében - elkezdett foglalkozni az ,energiamodulációs tömegspektrométer" matematikai elméletével. ${ }^{4}$

Mindeközben összetűzései voltak az egyetemi vezetőkkel „eretnek” javaslatai miatt. Például - a nélkülözhetetlen és nagyon fontos orosz nyelvi oktatás mellett - javasolta az angol nyelv oktatását is a szakirodalomra hivatkozva, azonban ez olyan felháborodást váltott ki, hogy hamarosan ávósok kezdték faggatni az angol titkosszolgálattal való kapcsolatairól. ${ }^{1}$

Folyamatosan tiltakozott a tisztogatási akciók ellen, amelyek során hallgatókat távolítottak el az egyetemről, hogy ezzel megfélemlítsék a többieket. 1954-ben Természettudományi Kar pedagógus szakszervezetének a sportfelelőse lett, majd a TTK Haladás sportkör elnöke. 1957-ben - már választás útján - az újjáalakuló BEAC elnöke. „1956-ban azután, amikor megválasztottak a Természettudományi Karon a forradalmi bizottság elnökének, ezekből a fiúkból alakult meg a testőrségem. Segítségükkel sikerült megóvnunk a Természettudományi Karunkat"**

Az 1956-os forradalom alatt az Eötvös Egyetem Természettudományi Kara Forradalmi Bizottságának elnökévé választják, nem kis vita után. Október 22-én érkezik haza Prágából, ekkor értesül róla, hogy másnap elmaradnak az órák, mert nagygyülés lesz a Gólyavárban. Ezen sokan a radikális fellépést követelték, azonban Pista bácsi az egyetem eszközeinek megőrzését és az oktatás mielőbbi újraindítását szorgalmazta: „Ezért mindenkit arra kértem, ne ragadtassa magát semmiféle oktalan és értelmetlen cselekedetre."**

A vitát követően Lengyel Béla rektorhelyettes javaslatára megszavazták a forradalmi bizottság elnökének. „Jó kapcsolatban álltam a hallgatókkal, az egyetemi sportklub, a TTK Haladás elnökeként jól ismertem kosarasainkat és futballistáinkat. Úgy 30-40, colos gyereket rögtön beállítottam kapuörségbe, beosztottam az egyetem területén belüli rendfenntartásra." November 9-én összehívta a csapatot: „megköszöntem nekik, hogy ilyen odaadással örizték az egyetemüket, és hazaküldtem őket".*

A forradalom leverését követően a dékán - figyelembe véve, hogy a Természettudományi Karon mindössze egyetlen ablakbelövés történt - kormánykitüntetésre akarta felterjeszteni, azonban az irigység és a féltékenység közbeszólt: egy feljelentést kreáltak ellene, amit igyekeztek hamis papírokkal alátámasztani. Ennek következtében az 1956-os eseményekben való részvételéért 2 hónap börtönre ítélik és ,,halmazati büntetésként" a felsőoktatásból, és általában mindennemü szellemi munkavégzésből kirekesztik, így a börtönt követően nem végezhetett csak fizikai munkát. 1957 és 1964 közötti időszakban azonban csak müszerészként tudott elhelyezkedni az akkoriban a szocialista nagyüzemek zászlóshajójának számító Borsodi Vegyi Kombinátban (2. ábra) (BVK, ma BorsodChem Zrt.). Szerencsére az utóbbi „büntetésen” az évek folyamán ,„puhítottak”, így később lehetővé vált számára, hogy oktatóként a felsőoktatásban is részt vehessen.

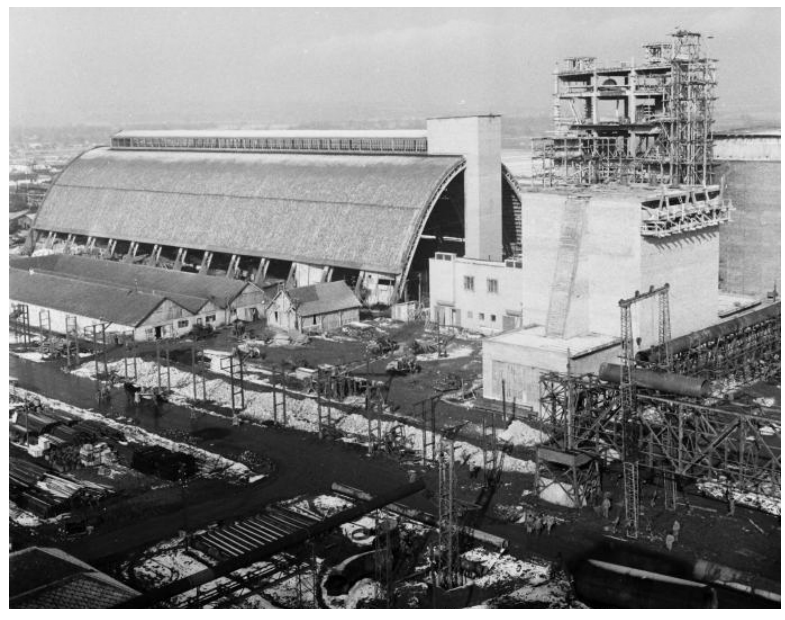

2. ábra. A Borsodi Vegyi Kombinát (BVK) kazincbarcikai telephelyének részlete 1955-ben. (forrás: Fortepan/Kotnyek Antal) 
A BVK-ban elvégzendő müszerészi feladatok nem álltak távol tőle, hiszen korábbi munkahelyén a gyakorlati fizikai laboratórium müszeres hátterének biztosítása és karbantartása is a felügyelete alá tartozott. Ebben az időben azonban a ,szellemi” áttörést a BVK akkori vezérigazgatójának megbízása hozta meg számára, aki a termeléshez szükséges korszerü analitikai módszereket, müszeres technikákat, de elsősorban a tömegspektrometriát szerette volna adaptálni, és ebben nagymértékben számított Cornides Istvánra. Cornides ekkor jelezte a vezérigazgatónak, hogy a fennálló eltiltás miatt csak fizikai munkát végezhet, mire a vezérigazgató így felelt: „Nem érdekes, különben is fizikus, fizikai munkás majdnem ugyanúgy hangzik." A BVK-ban Cornides István egyértelmüen bizonyította, hogy nemcsak kiváló fizikus, de a vegyészet sem áll távol tőle, és képes komoly technológiai problémák megoldására, amint azt „éles” helyzetekben többször is demonstrálta. Az egyik ilyen súlyos technológiai probléma az ammóniaszintézis során keletkezett a BVK-ban, amely a termelés teljes leállásához vezetett. Cornides a szintézishez felhasznált és keletkezett gázminták tömegspektrometriás vizsgálatával meggyőzően kimutatta, hogy a technológiai probléma okozója az argon nem várt feldúsulása a reakcióelegyben. Cornides eredményeinek figyelembe vételével a technológiai „gyengeséget” kiküszöbölték, így az üzem a későbbiekben már problémamentesen müködött. Eredményei arra is ösztönözték, hogy az argon oldhatóságát folyékony ammóniában részletesebben is tanulmányozza és a vizsgálati eredményeket publikálja. $^{6}$

Tömegspektrométerével (amelyet úgy csempésztek be az országba egy dán halkereskedő segítségével, aki Brémában vásárolta, Trieszten és Prágán keresztül juttatta el Budapestre) ezután nagyon sok szép további mérési eredményt sikerült elérnie, amelyeket Schulek Elemér is örömmel fogadott.

Kandidátusi disszertációja is ilyen gyakorlati, ipari feladatokhoz kapcsolódó tudományos eredményekre épült, amit 1968-ban védett meg. A védés után odajött hozzá Simonyi Károly, aki tagja volt ennek a bizottságnak: „Tudod, ezek a vegyészek nagyon rendesek veled. A bizottság döntésébe azt is beleírták, hogy javasoljuk, minél előbb adja be a doktori disszertációját." Ezt egyébként sohasem nyújtotta be.

Az üzemben végzett kiváló munkájának, elismert problémamegoldó képességének és nem utolsó sorban az oktatás iránti elkötelezettségének köszönhetően a Nehézipari Minisztérium engedélyével ebben az időszakban már taníthatott a Kazincbarcikai Vegyipari Müszerezési és Automatizálási Technikumban, amelynek egyik alapító tagja is volt (3. ábra) (későbbi nevén Miskolci Nehézipari Egyetem Vegyipari Automatizálási Főiskolai Kar). ${ }^{3}$

Cornides István „barcikai” diákokhoz füződő viszonyáról sokat elárul a „Tíz éve már” címü, feltehetőleg Cornides által „,tollba mondott” és Kovács Béla, az intézmény egykori hallgatója által lejegyzett költemény ${ }^{3}$ alábbi két versszaka is:

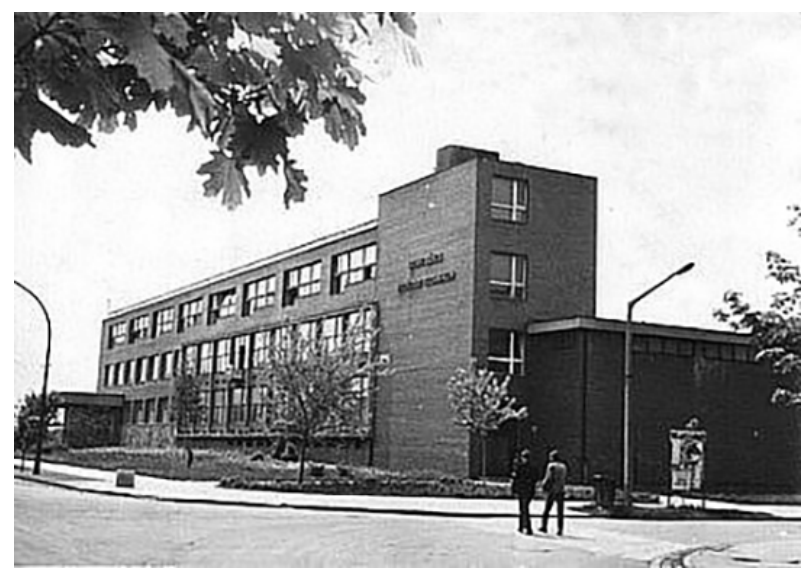

3. ábra. Kazincbarcikai Vegyipari Műszerezési és Automatizálási Technikum (forrás: http://5165.partner.net-tech.hu)

„Szerettelek titeket is »ifjú tanítványok«

Akkor is, ha nem ment mindig jól a »fizikátok«

Szerettem veletek a sportot üzni, A természetet közösen »legyürni«,,

\section{„Gondoltok-e néha rám, volt »Barcikai Diákok«, Mikor néha a közös múltra gondoltok? \\ No nem a fizikára, a »tanárra«, \\ Aki a »tantárgyat« más »dimenziókban« is látta!"}

1964-ben kinevezik egyetemi docensnek és megbízzák a Miskolci Nehézipari Egyetem Fizika Tanszékének vezetésével, azonban 1966-ban, politikai okból innen is távoznia kellett. 1966-tól a Bányászati Kutatóintézet tudományos munkatársaként és az intézet Tömegspektrometriai Laboratóriumának vezetőjeként dolgozott 1985 évi nyugdíjba vonulásáig. Oktatás iránti elkötelezettsége, tanári elhivatottsága és szülőföldje iránt érzett szeretete is arra késztették 1968-től kezdődően, hogy aktívan részt vegyen a fizika és kémia tanár szakos hallgatók oktatásában a Nyitrai Pedagógiai Főiskolán, majd az ebből átszervezett Konstantin Filozófus Egyetemen. A rendszerváltás után, a szlovák kormány lehetővé tette számára, hogy vendégprofesszorként hivatalosan is itt taníthasson. Cornides István vallotta, hogy a kutatás az oktatás szerves részét kell, hogy képezze, színvonalas modern oktatás pedig csak ott valósítható meg, ahol az oktatók az oktatott területük magas szintü müvelői is egyben. Ennek megfelelően a Konstantin Filozófus Egyetemen tömegspektrometriás kutatócsoportot hozott létre, amely különböző összetételü, gázfázisú klaszterek képződésének és tulajdonságainak vizsgálatában ért el nemzetközileg is jelentős eredményeket. Összefüggést állapítottak meg például a periódusos rendszer III. csoportjában található elemek oxidjainak $\left(\mathrm{M}_{2} \mathrm{O}_{3}\right)$ kémiai tulajdonsága és az adott elemböl (M) oxigén jelenlétében, elektromos kisülések hatására képződő klaszter-oxid részecskék $\left(\mathrm{M}_{\mathrm{x}} \mathrm{O}_{\mathrm{y}}\right)$ száma között. ${ }^{7}$ Ilyen típusú összefüggések feltárásához nagy pontosságú tömegspektrometriás mérésekre volt szükség. 
Az 1990-es évek elején a kutatók figyelme a fullerénekre és képződésük mechanizmusának felderítésére irányult. ${ }^{8,9}$ A grafit magas hőmérsékletủ párologtatásával (pl. plazmában) a jól ismert $\mathrm{C}_{60}$ és $\mathrm{C}_{70}$ mellett szénklaszterek sokasága képződik. Megválaszolatlan kérdés volt ez idő tájt, hogy a szénklaszterek asszociációs úton, a $\mathrm{C}_{1}$ és $\mathrm{C}_{2}$ egységekből állnak-e össze és/vagy a nagyobb szerkezeti egységek fragmentációja során képződnek gázfázisban. Cornides Istvánék a kérdés megválaszolásához ötletes kísérletet terveztek ${ }^{13} \mathrm{C}$-mal dúsított bárium-karbonát és normál grafit felhasználásával. ${ }^{10}$ Vizsgálataik során megállapították, hogy a $\mathrm{C}_{2}$ egység a szénatomok asszociációjával képződik a plazmában, míg a nagyobb méretű szénklaszterek képződése asszociációs és fragmentációs utakon is megvalósulhat.

Cornides István és munkatársainak kutatási területét felölelte még a kis molekulatömegü, relatíve nagy töltésű (3+) részecskék képződésének és tulajdonságainak vizsgálata tömegspektrometriás körülmények között. ${ }^{11,12}$

„1966-ban oxigénizotópos vizsgálatot kezdtünk el annak érdekében, hogy a klasszikus geológiai (litológiai-petrográfiai) vizsgálatok lehetőségein túlmenően nyerhessünk felvilágosítást érctelérek keletkezési mechanizmusára vonatkozóan. Egyikünk (Kiss J.) elgondolásának megfelelően egy érctelér adott harántszelvényén vett kalcitminták oxigénjének izotópelemzésével a képződési hőmérséklet változásáról kívántunk képet kapni, lehetővé téve ezáltal a telérképződés időbeli lefolyásának közelebbi megismerését."13

Széleskörü érdeklődését jól bizonyítja, hogy egyaránt foglalkozott a titán(IV) meghatározásával növényi mintákban ${ }^{14}$, csakúgy, mint az egri gyógyvizek szervetlen száraz maradékának tömegspektrográfiás vizsgálatával. ${ }^{15}$

A különböző kutatásokban Cornides István 1999-ben bekövetkezett haláláig részt vett.

A tömegspektrometria és alkalmazása területén kifejtett munkásságát jól dokumentálja a több, mint 120 tudományos közleménye, összefoglaló, elemző cikke, könyvei és könyvfejezetei. Az 1975-ben megjelent „Gyakorlati tömegspektroszkópia" címü könyve az első magyar nyelvü, tudományos igényességgel megírt tömegspektrometriai témájú szakkönyv, amelyet „A kémia újabb eredményei” sorozatban publikált, a tömegspektrometria jelenét és jövőjét bemutató könyvfejezete követett (4. ábra).

Cornides István valamint Kovách Ádám és Szepesváry Pál kezdeményezésére alakult meg 1958-ban a Magyar Kémikusok Egyesülete Fizikai Kémiai, majd 1962-től az Alkalmazott Fizikai-kémiai Szakosztálya keretében a

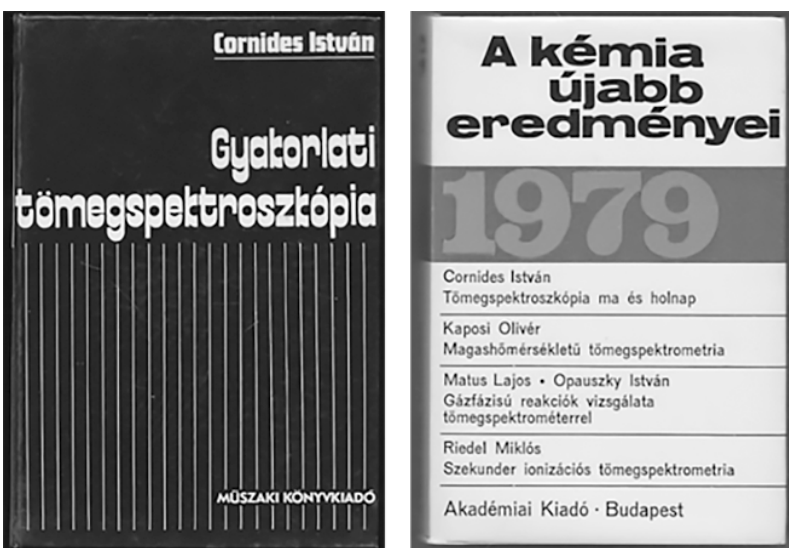

4. ábra. Cornides István tömegspektrometriai témájú könyvei

Tömegspektroszkópiai Szakcsoport, mely azóta is folyamatosan müködik a hazai tömegspektroszkópusokat összefogó szervezetként. A 70-es évek elején a Szakcsoport egyesült a Magyar Kémikusok Egyesülete Analitikai Kémiai Szakosztályával. A Szakcsoport elnökei voltak: Cornides István (1958 - 1964, 1970 - 1984 örökös tiszteletbeli elnöke 1994-től), Opauszky István (1965 - 1969), Tamás József (1985 - 1989, 1991 - 1993), Kaposi Olivér (1989 - 1990), Horváth Gyula (1994-2007), Lelik László (2007-2019), Vékey Károly (2019-).

A Szakcsoport 1994-től, a Magyar Kémikusok Egyesülete elnökségének hozzájárulásával, MKE Tömegspektrometriai Társaság néven, az egyesület szakosztályaként müködik.

Cornides István tagja volt az MTA Spektrokémiai Munkabizottság Izotópgeokémiai Munkabizottságának (1980-ig), és vezetőségi tagja a Magyar Kémikusok Egyesülete Analitikai Szakosztályának és az Alkalmazott Fizikai-kémiai Szakosztályának (1962-től).

Tagja volt a Japán Tömegspektroszkópiai Társaságnak (1976-1980), az International Scientific Committee of Mass Spectrometry-nek (1980-tól), ez utóbbinak elnöke is $(1992-1994) .^{16}$

Cornides István a tömegspektrometria nemzetközileg is elismert kutatójává vált, és ebből fakadóan számos konferencia felkért előadója és szervezője volt. Ezek közül kiemelendö, hogy 1988-ban a Bordeaux-i 11. International Mass Spectrometry Conference (IMSC) rendezvényén megszerezte az IMSC konferencia megrendezési jogát egy kelet-európai ország számára Budapesten. Az már a sors fintora, hogy erre 1994-ben kerül sor - a kelet-európai rendszerváltást követően - amikor már mindenki azzal a lehetőséggel akart élni, hogy szabadon utazhat nyugatra! 


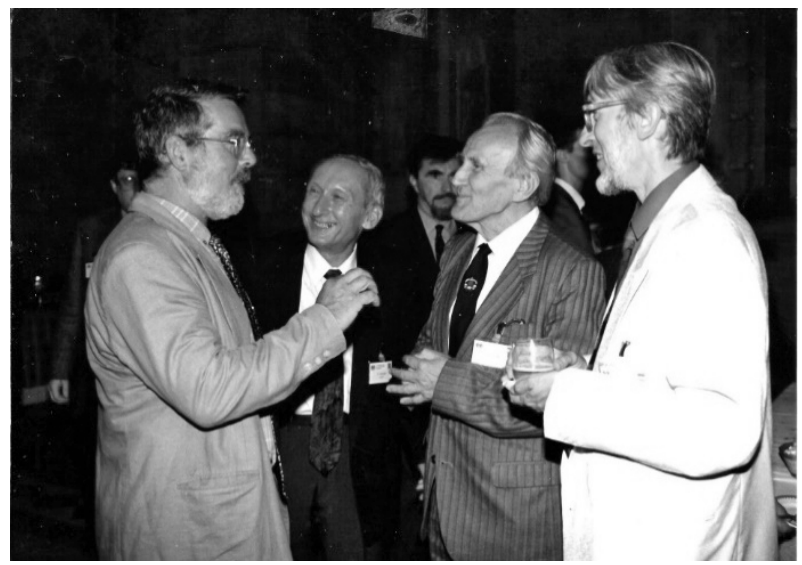

5. ábra. Diszkusszió a 13. IMSC kávészünetében

Képen balról jobbra: Prof. F. Rüdenauer (Bécs), Prof. V. Cserepin (Kijev), Cornides István, Riedel Miklós

Ezzel együtt olyan - több mint ezer résztvevős - konferenciát sikerült szerveznünk (elnézést, de Pista bácsi volt a Szervező Bizottság elnöke, én pedig a titkára L. L.), amire a mai napig szeretettel emlékeznek a résztvevők (5 - 6. ábra).

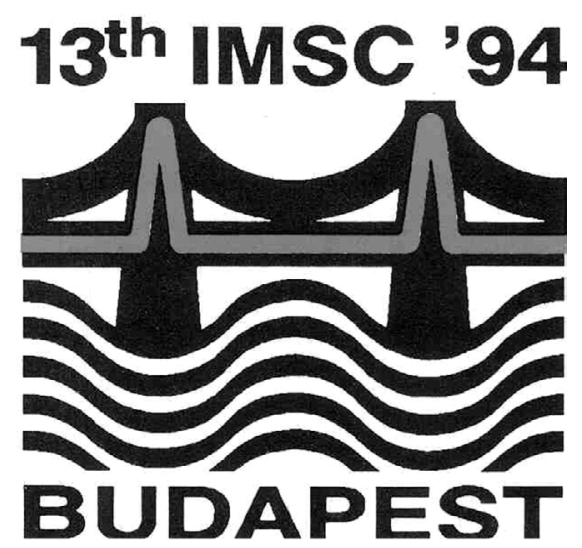

6. ábra. A Budapesten megrendezett 13. International Mass Spectrometry Conference (IMSC) logója (Andor András munkája).

Nemzetközi ismertségének köszönhetően vendégprofesszorként két ízben is részt vett a Tokiói Nemzetközi Egyetem oktatási és kutatási feladatainak ellátásában.

Cornides István a szakmai életútját keresztező méltánytalanság- és igazságtalanság-sokaságok ellenére, számos díjban és elismerésben részesült itthon és külföldön egyaránt: 1982-ben a Csehszlovák Tudományos Akadémia Johanes Marcus Marci emlékplakettjével tüntették ki, és 1999-ben megkapta a Konstantin Filozófus Egyetem ezüstérmét. Itthon 1992-ben a Magyar Köztársaság középkeresztjével, míg 1994-ben Than Károly emlékéremmel tüntettek ki, majd 1997-ben neki ítélték oda a Náray-Szabó István díjat.

Az ELTE 1990-ben rehabilitálta és részére címzetes egyetemi tanári titulust adományozott.
Cornides István fizikusként, az ELTE Fizikai Intézetében töltött évei alatt részt vett a vegyészképzés elindításában is, vegyész hallgatóknak laboratóriumi gyakorlatokat szervezett. Hallgatóként a csoportjába felvételt nyerni kiváltságnak számított. Olyan kiváló kutatók képzését segítette, mint Kálmán Alajos, Andy Grove, Nágel Ferenc, Opauszky István. Munkássága óta a tömegspektrometria fókuszpontja a fizika helyett a kémia és a biokémia területére helyeződött át. Bár emlékét az ELTE Természettudományi Karán tábla őrzi (7. ábra), az ELTE Kémiai Intézete egy, a nevét viselő kutató-oktató laboratórium megalapításával is szeretne munkásságának méltó emléket állítani.

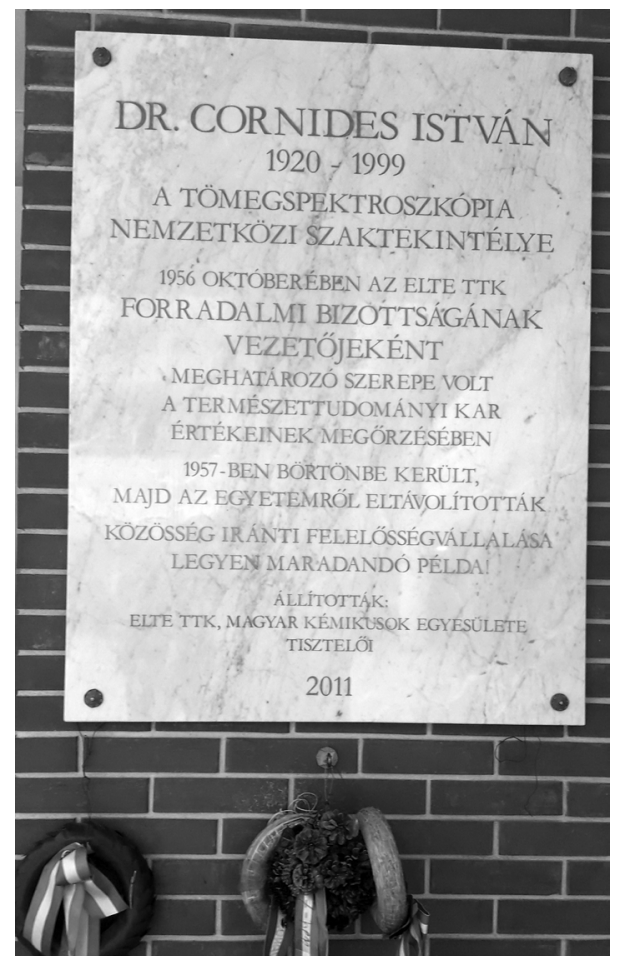

7. ábra. Cornides István emléktáblája az ELTE Aulájában.

Cornides István öröksége napjainkban is tovább él: egykori alma matere, a mai Selye János Magyar Gimnázium évente megrendezi felvidéki és magyarországi diákok részvételével a róla elnevezett „Cornides István matematikai-fizikai emlékverseny"-t. ${ }^{17}$ Cornides István özvegye minden tanév végén ösztöndíjat adományoz a gimnázium két kiválóan teljesítő diákjának. Itthon Cornides István munkássága előtti tisztelgésként a Magyar Kémikusok Egyesülete Tömegspektrometriai Társasága 2011-ben - Müller Tibor javaslatára - megalapította a „Cornides István Tudományos Díj"-at ${ }^{18}$ (8. ábra), amelyet a következő feltételekkel ítélnek oda: „A díjat a tömegspektrometria területén kiemelkedő eredményt elérő magyar kutató, oktató kaphatja. A kitüntetésre javaslatot az MKE Tömegspektrometriai Társaság vezetőségéhez lehet benyújtani. Az Emlékérmet az MKE Tömegspektrometriai Társaság Vezetősége évente ítéli oda. Az Emlékéremhez bruttó 1000 euro pénzjutalom társul.” 


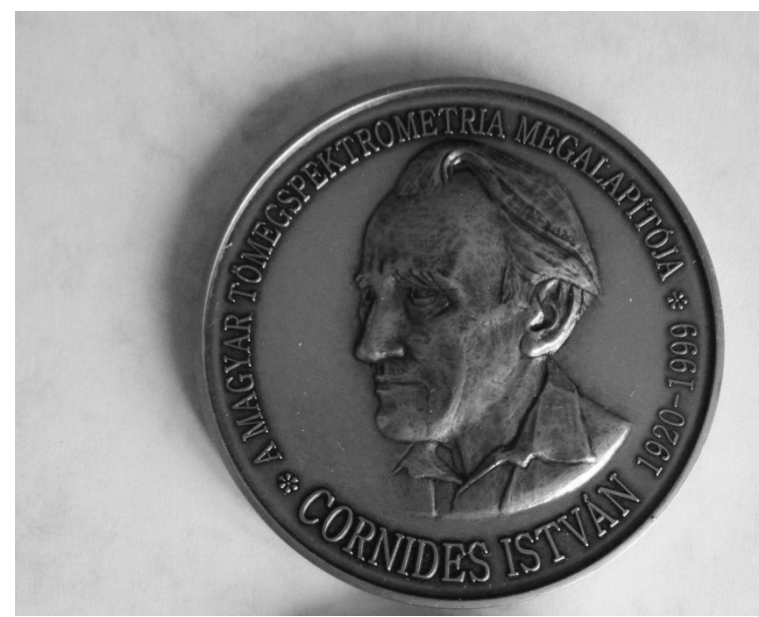

8. ábra. A Magyar Kémikusok Egyesülete Tömegspektrometriai Társasága által alapított „Cornides István Tudományos Díj” emlékérme (Albrecht Júlia alkotása).

A következő táblázat a Cornides István Tudományos Díjjal, 2011 és 2018 között kitüntetetteket mutatja be.

\begin{tabular}{|c|c|}
\hline Név & Odaítélés éve \\
\hline Újszászy Kálmán & 2011 \\
\hline Kéki Sándor & 2012 \\
\hline Drahos László & 2013 \\
\hline Czira Gábor & 2014 \\
\hline Schlosser Gitta & 2015 \\
\hline Szabó Pál & 2016 \\
\hline Riedel Miklós & 2017 \\
\hline Háda Viktor & 2018 \\
\hline
\end{tabular}

1. Táblázat. A 2011-2018 időszakban Cornides István Tudományos Díjjal kitüntetettek listája.

Cornides István szakmai teljesítményét és szellemi örökségét közleményei, könyvei, egyetemi és föiskolai jegyzetei méltóképpen dokumentálják. Cornides Istvánnak, mint tanárembernek a hitvallását, azonban az 1993-ban vele készített interjú zárómondatai fejezik ki talán a legjobban ${ }^{1}$ : az újságíró „Az sem bántott volna, hogy diákjaid mit gondolnak rólad, ha 1956-ban megfutamodsz és családoddal felülsz arra a Nyugatra tartó teherautóra?" kérdésére, a következőt válaszolta: „Látod, akkor többek között ez volt, ami visszatartott. Nagyon lesújtott volna, ha tanítványaim csalódottan kérdezik: »Még ez az ember is megszökött? Akkor kiben bízhatunk?« Egy tanárnak minden körülmények között morális példát kell adnia. Nem cselekedhet másként”.

Cornides István, hosszú, türelemmel viselt betegség után 1999. november 1-én hunyt el. Tanítványai nevében,
Horváth Domokos fizikus, e szavakkal búcsúzott el mesterétől: „Életedet a vak bosszú és a megtorlás kettétörte, de jellemedet, szellemedet nem tudták megtörni."

\section{Köszönetnyilvánítás}

Köszönjük özv. Dr. Cornides Istvánnénak - Pista bácsi özvegyének - hogy hüséges kísérője volt férjének Nyitrától Tokióig, és jelenlétével valamennyi Cornides Díj átadását megtisztelte. A szerzők köszönetüket fejezik ki neki a kézirat gondos átolvasásáért, hasznos megjegyzéseiért és tanácsaiért, amelyekkel segítette annak elkészülését. Hasonlóképpen köszönjük Riedel Miklósnak a szakértő és lelkiismeretes segítséget.

\section{Hivatkozások}

* idézet Cornides Istvántól

1. Staar Gyula: Tudóssors Közép-Európában (Beszélgetés Cornides István fizikussal. 2.) Valóság, 2007, 11, 93-113.

2. Barna B. Péter, Cornides István 1920-1999 Fizikai Szemle, 2000, 3, 95 .

3. http://5165.partner.net-tech.hu/DOKUMENTUMOK--IRASOK/Cornides-tanar-urra-emlekezve

4. Cornides, I. Acta. Phys. Hung. 1955, 5, 471-482., https://doi.org/10.1007/BF03156543

5. Cornides, I. A Magyar Tudományos Akadémia Központi Fizikai Kutató Intézetének közleményei, 1956, 6, 527-532.

6. Csekő, Gy.; Cornides, I. Journal of Inorganic and Nuclear Chemistry 1960, 14, 139-141. https://doi.org/10.1016/0022-1902(60)80217-5

7. Gál, T.; Sidó, Sz.; Cornides, I. Rapid Commun. Mass Spectrom. 1996, 10, 465-467. https://doi.org/10.1002/(SICI)1097-0231(19960315)10:4<46 $5::$ AID-RCM489 $>3.0 . C O ; 2-1$

8. Kroto., H. W.; Heath, J. R.; O'Brien, S. C.; Curl, R. F.; Smalley, R. E. Nature, 1985, 318, 162-163. https://doi.org/10.1038/318162a0

9. Kratschmer, W.; Lamb, L. D.; Fostiropoulos, K.; Huffman, D. R. Nature, 1990, 347, 354-358. https://doi.org/10.1038/347354a0

10. Cornides, I.; Morvay, L. Rapid Commun. Mass Spectrom. 1992, 6, 758-759. https://doi.org/10.1002/rcm.1290061209

11. Cornides, I.; Morvay, L. Int. J. Mass Spectrom. Ion Proc. 1984, 62, 263-268. https://doi.org/10.1016/0168-1176(84)87112-8

12. Morvay, L.; Cornides, I. Rapid Commun. Mass Spectrom. 1992, 6, 339-340. https://doi.org/10.1002/rcm.1290060505

13. Cornides I., Kiss J. Geonómia és Bányászat, 1971, 4, 313320

14. Cornides I., Pais I., Fehér D.-né, Kertészeti Egy. Közlem. 1975, 39, 213

15. Cornides I., Agyagási D. Gyógyfürdöügy 1978, 12, 9

16. http://www.nevpont.hu/view/9600

17. https://ma7.sk/kozelet/oktatas/bisten-aldja-a-porat-iscornides-istvannak

18. http://ms.elte.hu/?lap=CornidesDij 


\section{István Cornides (1920-1999), the founder of mass spectrometry in Hungary}

This article gives a comprehensive overview on István Cornides`s academic life, emphasizing his achievements in the field of higher education and mass spectrometry.

István Cornides was born on December 12, 1920 in Komjat. He was an excellent teacher and scientist who began his career under the supervision of the Nobel Laureate György Békésy. István Cornides made significant improvements in teaching physics not only for physicists but for chemists, too. Furthermore, from the early $50 \mathrm{~s}$, he started to work with mass spectrometry, which was an uncovered research area in Hungary at that time.

However, because of his relationship with the actual communist political power, between 1957 and 1964 his teaching and scientific activities were rather limited and controlled, and he was able to continue his work only as a technician at the BVK, the leading chemical company at that time. The "intellectual" breakthrough arrived to him when he was charged of adapting modern analytical techniques such as mass spectrometry (in particular) by the BVK's CEO. Reflecting to this charge, Cornides turned to the CEO that he was allowed to do manual work only because of his existing restriction. Then the CEO said, "It doesn't matter. Anyway, physicist, physical worker sounds almost the same. At the BVK, however, István Cornides unambiguously demonstrated that he was not only an excellent physicist, but the chemistry was not far behind either, and he was able to solve serious technological problems, as he had proved that several times in "live" situations. One of the most serious technological failures at the BVK at that time occurred in connection with the synthesis of ammonia. István Cornides pointed out clearly by means of his very precise mass spectrometric measurements that the technological failure was due to an unexpected accumulation of the Argon gas in the reaction mixture.

As his work and innovations were recognized, he was allowed to teach at the Chemical Instrumentation and Automation College of Kazincbarcika, of which he was one of the founders. Later, he was appointed to the Department of Physics of the University of Miskolc, from which in 1966, due to political reasons, was dismissed. From that time until his retirement (1985) he worked for the Mining Research Institute as the head of the Laboratory for the Mass Spectrometry.

His commitment to education and love for his homeland inspired him, from 1968, to participate actively in teaching physicist and chemist students at the Nitra College of Pedagogy. Soon after the change of the political system, the Slovak government allowed him to teach officially here as a visiting professor. István Cornides admitted that the research should be an integral part of the education system, and high-quality, modern education can exist only if the teachers are high-level practitioners in their area of education.

Accordingly, he established a mass spectrometry research group at the Constantine the Philosopher University in Nitra. This group has achieved internationally significant results in the study of formation and properties of gas-phase clusters with various compositions.

István Cornides, as a physicist, also promoted and participated in the launch of training chemists at the Institute of Physics, ELTE, organized and conducted laboratory practices for chemist students. Interestingly, it was a privilege for a student to be a member of his group. During his career he helped train such excellent researchers as Alajos Kálmán, Andy Grove, Ferenc Nágel and István Opauszky, among many others.

His achievements in mass spectrometry and its applications are well-documented in more than 120 scientific publications, review, books and book chapters. Furthermore, his book entitled "Practical Mass Spectroscopy", published in 1975, is the first book on mass spectrometry written in Hungarian.

Even after his retirement, he remained a very active teacher, scientist and organizer as demonstrated by his several publications, lectures at the Constantin Philosopher University in Nitra, and organization of the $13^{\text {th }}$ International Mass Spectrometry Conference (IMSC).

The intellectual heritage of István Cornides is still exists today: his former alma mater, the János Selye Grammar School, organizes annually the „István Cornides mathematical-physical memorial competition" with the participation of students from Hungary and Slovakia. Furthermore, at the end of each school year, the widow of István Cornides offers scholarships to two excellent students from the János Selye Grammar School. In addition, in Hungary, in honor of the achievements of István Cornides, the Mass Spectrometry Group of the Hungarian Chemical Society established the István Cornides Scientific Prize in 2011.

István Cornides died after a long-term illness on November 1, 1999. At his funeral, on behalf of his students, physicist Domokos Horváth said goodbye to his teacher with these touching words: "The blind revenge and retribution had broken your life, but your character and spirit could not had been destroyed." 